\title{
Whose Pharaohs?
}


This page intentionally left blank 


\section{Whose Pharaohs?}

Archaeology, Museums,

and Egyptian National Identity from Napoleon to World War I

Donald Malcolm Reid

UNIVERSITY OF CALIFORNIA PRESS

Berkeley . Los Angeles . London 
Portions of this book have appeared previously in different form as "Archeology, Social Reform, and Modern Identity among the Copts, I854-I952,” pp. 3I I-35 in Entre Réforme sociale et mouvement national: Identité et modernisation en Égypte (I882-I962), edited by Alain Roussillon (Cairo: Centre d'études et de documentation économiques, juridiques et sociales, I995); "Cromer and the Classics: Imperialism, Nationalism, and the Greek and Roman Past in Modern Egypt," Middle Eastern Studies I 8 (1996): 73-90, Frank Cass Publishers, London; "Cultural Imperialism and Nationalism: The Struggle to Define and Control the Heritage of Arab Art in Egypt," International Journal of Middle East Studies 24 (I992): 57-76, Cambridge University Press; "French Egyptology and the Architecture of Orientalism: Deciphering the Facade of Cairo's Egyptian Museum," pp. 35-69 in Franco-Arab Encounters: Studies in Memory of David C. Gordon, edited by L. Carl Brown and Matthew Gordon (Beirut: The American University in Beirut, I996); "Indigenous Egyptology: The Decolonization of a Profession?" Journal of the American Oriental Society IO5 (I985): 233-46; and "Nationalizing the Pharaonic Past: Egyptology, Imperialism, and Egyptian Nationalism, I922-I952," pp. 35-69 in Rethinking Nationalism in the Arab Middle East, edited by Israel Gershoni and James Jankowski (New York: Columbia University Press, I997), (C) 1997 Columbia University Press. Reprinted by permission of the publisher.

University of California Press

Berkeley and Los Angeles, California

University of California Press, Ltd.

London, England

(C) 2002 by The Regents of the University of California

Library of Congress Cataloging-in-Publication Data

Reid, Donald M. (Donald Malcolm).

Whose pharaohs? : archaeology, museums, and Egyptian national identity from Napoleon to World War I / Donald Malcolm Reid.

p. $\mathrm{cm}$.

Includes bibliographical references and index. ISBN 0-520-22I97-4 (cloth : alk. paper)

I. Egypt-Antiquities. 2. Archaeology-

Egypt-History. 3. Archaeological museums and collections-Egypt-History.

4. Egyptology-History. 5. NationalismEgypt-History. I. Title.

DT56.9 .R45 2002

$932-\mathrm{dc} 2 \mathrm{I}$

O०-0475 I 8

CIP

Manufactured in the United States of America

$\begin{array}{llllllllll}\text { II } & \text { IO } & 09 & 08 & 07 & 06 & 05 & 04 & 03 & 02 \\ \text { IO } & 9 & 8 & 7 & 6 & 5 & 4 & 3 & 2 & \text { I }\end{array}$

The paper used in this publication meets the minimum requirements of ANSI/NISO Z39 0.48-I992 (R I997) (Permanence of Paper). ${ }^{\circledR}$ 
For Barbie 
This page intentionally left blank 